\title{
A ARMADILHA DO TRABALHO: REFLEXÕES SOBRE TEMPO, DINHEIRO E PREVIDÊNCIA
}

\author{
Daniel Viana Teixeira
}

\section{RESUMO}

A CRISE FINANCEIRA INTERNACIONAL REAVIVOU O DEBATE SOBRE O PAPEL DO ESTADO NA ECONOMIA E SOBRE A TENSÃO ENTRE O ENDIVIDAMENTO PÚBLICO E A CRESCENTE DEMANDA POR PRESTAÇÕES SOCIAIS DE SAÚDE, PREVIDÊNCIA E ASSISTÊNCIA. SENDO O CUIDADO E A ASSISTÊNCIA ESSENCIAIS PARA A MANUTENÇÃO DA VIDA HUMANA EM SOCIEDADE, A SIMPLES RESTRIC̣ÃO DESSAS PRESTAC̣ÕES ESTATAIS - RECOMENDACÃO TÉCNICA RECORRENTE PARA A SOLUÇÃO DO PROBLEMA - NÃO PARECE SER UMA ALTERNATIVA. DADOS OS INCENTIVOS E INJUNÇÕES SOCIAIS PARA QUE OS INDIVÍDUOS BUSQUEM TRABALHO REMUNERADO E SE AFASTEM DAS NECESSIDADES DO AMBIENTE FAMILIAR, CABERIA UM REEQUILIIBRIO ENTRE OS INCENTIVOS SOCIAIS A ESSAS DIFERENTES MODALIDADES DA ATIVIDADE HUMANA. OS SISTEMAS PÚBLICOS DE PREVIDÊNCIA PODEM FUNCIONAR COMO INSTRUMENTO PARA O OFERECIMENTO DE CONDICTÕES MATERIAIS PARA QUE OS INDIVÍDUOS POSSAM, ELES MESMOS, PROVER O CUIDADO E A ASSISTÊNCIA DE QUE SUAS FAMÍLIAS E PESSOAS PRÓXIMAS NECESSITAM, PELA GARANTIA, NO MOMENTO CERTO, DE TEMPO E ESTABILIDADE ECONÔMICA.

\section{PALAVRAS-CHAVE}

Dívida Pública; Previdência social; Mercado de TRABALHO; ECONOMIA FAMILIAR; CUIDADO E ASSISTÊNCIA.

\begin{abstract}
THE INTERNATIONAL FINANCIAL CRISIS HAS REVIVED THE DEBATE ABOUT THE ROLE OF GOVERNMENT IN THE ECONOMY AND ON THE TENSION BETWEEN PUBLIC DEBT AND RISING DEMAND FOR SOCIAL SERVICES OF HEALTH, WELFARE AND ASSISTANCE. BEING CARE AND ASSISTANCE ESSENTIAL FOR SUSTAINING HUMAN LIFE IN SOCIETY, THE MERE RESTRICTION OF THESE STATE BENEFITS - RECURRING TECHNICAL RECOMMENDATION FOR THE SOLUTION OF THE PROBLEM SEEMS NOT TO BE AN ALTERNATIVE. GIVEN THE INCENTIVES AND SOCIAL INJUNCTIONS FOR INDIVIDUALS TO SEEK PAID WORK AND NOT DEPART FROM THE NEEDS OF THE HOUSEHOLD ENVIRONMENT, IT SHOULD BE A BALANCE BETWEEN SOCIAL INCENTIVES TO THESE DIFFERENT MODES OF HUMAN ACTIVITY. THE PUBLIC WELFARE SYSTEMS CAN FUNCTION AS AN INSTRUMENT FOR THE DELIVERY OF MATERIAL CONDITIONS SO THAT INDIVIDUALS CAN, THEMSELVES, PROVIDE CARE AND ASSISTANCE THAT THEIR FAMILIES AND PEOPLE CLOSE NEED, ENSURING, AT THE RIGHT MOMENT, FREE TIME AND ECONOMIC STABILITY.

KEYWORDS

PUBLIC DEBT; WELFARE; LABOR MARKET; HOUSEHOLD ECONOMY; CARE AND ASSISTANCE.
\end{abstract}

\section{INTRODUÇÃO}

Nos últimos anos o mundo tem acompanhado o desenrolar de seguidas crises econômicas internacionais, que desta vez atingem os países centrais do sistema capitalista. A repetição dessas crises pode ser entendida como o resultado de uma permanente tensão entre o princípio básico de organização e reprodução do sistema capitalista, 
que deve orientar a ação dos indivíduos, e a necessidade de justificações e estímulos para que esses últimos mantenham-se engajados voluntariamente nesse modo específico de organização da produção e de ordenação social. Voltado à acumulação ilimitada de capital, objetivo posto como um fim em si mesmo, desvinculado de qualquer objetivo moral ou de outra ordem, o capitalismo é um sistema que necessita buscar justificações e estímulos à mobilização dos indivíduos fora de si. Em geral, articula-se o objetivo da acumulação com a promoção ou favorecimento de outros objetivos sociais de ampla aceitação, histórica e culturalmente variáveis.

O chamado "Estado de bem-estar" pode ser interpretado como um complexo institucional que funciona como mediador dessa tensão sistêmica. Aparentemente, o que as últimas crises econômicas nos revelam é a progressiva exaustão desse modelo institucional como meio eficaz para impedir que um sistema de organização social autocentrado, portanto não racional, deprima demasiadamente as condições de vida das sociedades e esgote os recursos naturais e humanos de que necessita. ${ }^{1}$

Não por acaso as reformas institucionais propostas como saída para a crise pelos países europeus desenvolvidos é centrada na reforma (redução) dos mecanismos de proteção social, com destaque para os sistemas públicos de previdência. As lideranças políticas parecem acreditar que a solução para a crise - caracterizada por baixo crescimento econômico associado a elevado endividamento - está na liberação do princípio de acumulação capitalista das peias institucionais que lhes impõem algum limite. Parece não haver uma compreensão clara de que o enfraquecimento de mecanismos de proteção social, já desgastados ao longo do tempo, expõe o sistema como um todo a riscos muito maiores que aquele decorrente do mero desequilíbrio fiscal. Tais mecanismos, ainda que desgastados, são atualmente os mediadores da tensão sistêmica a que nos referimos e que emprestam algum sentido de racionalidade à ordem social capitalista. Se não há dúvida de que os mecanismos de proteção social característicos do "Estado de bem-estar" precisam ser reformados, é evidente que eles não podem ser simplesmente suprimidos ou reduzidos sem a proposição de um substituto adequado.

A partir da reflexão sobre a questão previdenciária em meio a crises econômicas internacionais, esperamos tornar mais clara a compreensão de um contexto problemático mais amplo que remete ao reconhecimento da necessidade de encontrar novas formas de justificar a acumulação capitalista reduzindo a tensão sistêmica que esta mantém com a necessidade humana de emprestar sentido e racionalidade à vida. Para tanto, sugere-se uma análise crítica sobre o modo como o sistema produtivo envolve os indivíduos e o Estado num impasse difícil de resolver, pois exige cada vez mais eficiência e produtividade ao passo que deprime as condições de manutenção e reprodução do organismo social: os indivíduos se veem obrigados a se dedicar cada vez mais ao trabalho e menos à família; já o Estado é pressionado a reduzir impostos e cortar gastos sociais. Nossa hipótese é que a resolução desse impasse, que aqui chamamos 
de "armadilha do trabalho", passa pelo reconhecimento da incapacidade do "Estado de bem-estar" de substituir integralmente os indivíduos e as famílias no provimento de prestações de cuidado e assistência essenciais para a garantia de condições de vida minimamente dignas. Propõe-se a criação de mecanismos de proteção social que garantam tempo livre e segurança econômica no momento certo aos indivíduos, de modo não necessariamente vinculado ao exercício de atividade econômica remunerada. Esses mecanismos são importantes tanto para o enfrentamento de contingências indesejadas da vida, quanto, principalmente, uma forma de investimento na formação e reprodução do "insumo" econômico e social mais valioso: as pessoas.

\section{i Crise finACEIRA E Reforma dos Sistemas de PREVIDÊNCIA}

Como decorrência de seguidas crises econômicas internacionais nos últimos anos, em um curto espaço de tempo, os discursos político-econômicos de inspiração neoliberal praticamente deixaram de ser tomados a sério, e a percepção da necessidade de intervenção do Estado na economia, como única opção para salvar o sistema do colapso, mostrou-se tão evidente que sequer foi objeto de contestação.

Não há novidade nesse fato. As condições necessárias para o funcionamento adequado de uma economia de mercado não seriam possíveis sem a intervenção "artificial" do Estado, que passou a responder por um arcabouço de políticas assistenciais e previdenciárias em favor da sociedade em geral, garantindo aos indivíduos condições básicas de subsistência e reprodução, em troca da manutenção da ordem, sem o que se teria tornado insustentável a geração de um contingente estável de mão de obra disponível para a produção e a formação de um mercado consumidor dos bens produzidos. Também assumiu a responsabilidade por dotar parte dessa mão de obra de níveis mais elevados de instrução, além de investir diretamente na produção de conhecimento e desenvolvimento de tecnologia, providências essenciais requeridas pelo sistema econômico. É, ainda, responsável por manter uma infraestrutura pública de transportes, comunicações e energia, cuja criação e manutenção não se justificariam sem as necessidades específicas de um amplo e custoso sistema de produção e distribuição de bens e serviços. Além desses investimentos materiais, intervém o Estado normativamente no mercado ao disciplinar e coibir práticas anticoncorrenciais, ao empregar diversos mecanismos de política monetária no controle da inflação e do fluxo e oferta de capitais, ao adotar políticas para a regulação e estabilização de preços de insumos e produtos, etc.

Essas atividades colocam o Estado numa posição muito diferente da que se lhe pretendia atribuir no passado, quando se cultivava a imagem do mercado autorregulável e se pregava um mínimo de intervenção estatal. A economia de mercado depende cada vez mais da intervenção "artificial” - normativa e material - do Estado, para a manutenção das condições necessárias ao seu funcionamento. 
Há, do ponto de vista político, uma relação de dependência entre o Estado, o mercado e a sociedade civil. Argumenta-se que, embora necessite de todas essas intervenções para seu funcionamento, o mercado fornece ao Estado, por meio de impostos, os recursos necessários para financiar não apenas as atividades que diretamente lhe aproveitam economicamente, mas também todas as políticas assistenciais, previdenciárias e de serviços públicos destinadas aos cidadãos em geral, de cujo voto dependem os governos democráticos para se legitimar. Embora, na prática, toda a sociedade arque com os custos necessários para a manutenção das atividades estatais e suporte as consequências indesejadas da atividade econômica, atribui-se primordialmente à economia de mercado e à ordem dela decorrente o efeito de dotar a sociedade da capacidade de geração de riquezas tributáveis em grande escala.

Nessa relação triangular, a manutenção do bom funcionamento do mercado em conjunto com a promoção do crescimento econômico é apresentada como o único meio adequado para viabilizar o interesse de todas as partes envolvidas. Se o discurso político tende a defender uma ordem econômica concentradora de riquezas e promotora de desigualdades, tal defesa se apoia, paradoxalmente, no objetivo político da distribuição - sob a forma de salários, serviços públicos e prestações assistenciais e previdenciárias - de parte dessa riqueza, que, se alega, de outra forma não se teria produzido na mesma escala. Mas nessa relação simbiótica o sistema produtivo não figura apenas como provedor de injunções positivas. Especialmente em períodos de crise do sistema econômico, o Estado é chamado a intervir para restabelecer as condições necessárias ao seu bom funcionamento: provendo estímulos diretamente, investindo/financiando/subsidiando a atividade produtiva ou, indiretamente, cortando impostos, o que possibilita o aumento das margens de lucro que podem ser investidos no sistema.

Contudo, a intervenção estatal encontra limites na necessidade de manter as contas públicas equilibradas. Se o sistema produtivo pressiona o Estado por incentivos, o sistema financeiro, detentor dos títulos da dívida pública, pressiona no sentido contrário, buscando garantias de solvência do Estado - conquanto seja praticamente impossível reconhecer clara independência entre os interesses do setor produtivo e do setor financeiro. Quando o desequilíbrio das contas públicas alcança um ponto crítico, e os credores da dívida pública começam a cogitar a possibilidade do calote, o aumento de impostos não se mostra uma alternativa viável, pois desestimularia a atividade econômica já carente de incentivos. Isso parece ter acontecido a partir de 2008 em países europeus considerados desenvolvidos, como Grécia, Irlanda, Portugal, Espanha e Itália, deixando países centrais do sistema capitalista mundial, como Estados Unidos, Grã-Bretanha, França e Alemanha em alerta, ante a possibilidade de uma crise sistêmica, de proporções ainda maiores do que a crise financeira que desencadeou o processo, a partir da falência de instituições financeiras norte-americanas. 
Parece não restar alternativa para conciliar os interesses em questão - do sistema financeiro e do sistema produtivo - senão o corte de gastos. Como os gatos públicos são também um elemento importante na formação de demanda do sistema econômico, é preciso direcionar os cortes para despesas com o custeio de atividades comumente consideradas improdutivas, dentre as quais se pode destacar saúde, educação e previdência. Quanto aos interesses dos trabalhadores e da população em geral, prejudicados com os cortes em gastos sociais, alega-se ser esse o único modo de restaurar a prosperidade econômica, considerada pela ética capitalista a chave para a felicidade de todos ou do maior número. Os cortes são justificados como um sacrifício em nome da restauração da prosperidade econômica. Trocam-se prestações sociais do Estado pela geração de empregos no setor produtivo.

Dentre as políticas fiscais adotadas para o enfretamento de crises desse tipo no sistema econômico, ressalta a relevância que de modo recorrente se dá à necessidade de reformas nos sistemas públicos de previdência. O sistema econômico pressiona o Estado, por exemplo, pelo aumento ou estabelecimento de idades mínimas mais elevadas para as aposentadorias custeadas pelos sistemas públicos de previdência e outras modalidades de restrições ao acesso a benefícios. Alega-se que essas despesas afetam demasiadamente o equilíbrio das contas públicas, tendo em vista o aumento da expectativa de vida das populações, que passam a auferir por um período mais longo os benefícios custeados pelo sistema. Mas qual a razão desse enfoque específico? Por que para um problema aparentemente tão complexo, que envolve o modo como a sociedade distribui os benefícios e os encargos da vida em comum, se aponta quase em uníssono como solução o aumento dos encargos que recaem sobre a parcela mais frágil e desprotegida da sociedade?

\section{TEMPO E DINHEIRO}

A capacidade para o pensamento abstrato e hipotético é característica das mais notáveis do ser humano quando comparado a outras formas de vida animal. Por meio dessas ferramentas mentais ele planeja o futuro, organiza suas relações sociais, sonha, descreve a natureza de acordo com suas ideias e conceitos, enfim, dá sentido à sua existência e ao mundo ao seu redor. Possivelmente essa característica da condição humana imponha a permanente necessidade de preencher de sentido suas realizações pessoais e coletivas e até eventos naturais. Uma necessidade que pode ser por vezes angustiante, mas tem conduzido homens e mulheres a grandiosas realizações, boas e más.

O trabalho pode ser considerado uma das atividades humanas mais valorizadas. É possível perceber a importância que damos ao trabalho quando lembramos, por exemplo, que reservamos para ele especialmente as melhores horas do dia, quando há luz e estamos alertas, e com frequência avançamos pela noite. Os anos de nossa 
vida em que temos maior vigor físico e mental são também destinados principalmente a essa atividade. Nossa educação é voltada prioritariamente à preparação para o mercado de trabalho - o que claramente tem superado outros objetivos como a formação do caráter pelo ensino de valores humanos tão ou mais importantes quanto à capacitação profissional.

Esses fatos, dentre outros, reforçam a percepção de que para o senso ético das sociedades contemporâneas o trabalho figura como um valor fundamental, importante por si mesmo, e não meramente em função de eventuais frutos que ele possa proporcionar. Mas nem toda atividade laboral é valorizada da mesma forma. Há trabalhos mais ou menos valiosos segundo os critérios do senso ético das sociedades capitalistas que reservam esse julgamento para o mecanismo pretensamente imparcial do mercado, regido, segundo se acredita, pela lei da oferta e da procura. Nesse ponto, vislumbra-se uma importante característica do trabalho: a de ser um bem cujo valor depende em grande medida de estar submetido à lógica de mercado. Ele precisa ser intercambiável, negociável. Diferentes tipos de trabalho - do padeiro ao cientista nuclear -, que são por natureza incomensuráveis, precisam ser medidos e valorados segundo padrões que tornem possível uma comparação, fundamental para a negociação mercantil. O tempo e o valor monetário, características abstratas que a mente humana agrega ao trabalho, são padrões que possibilitam essa comparação. Por meio dessas abstrações dá-se sentido e valor ao evento fático da atividade laboral.

O modo como uma sociedade se organiza não é mera função de disposições naturais dos seres humanos. Ao substrato concreto de sua conduta o ser humano acrescenta significados e valores. Para que uma sociedade adote determinado modo de organização da produção e certo modo de distribuição dos ônus e benefícios decorrentes da vida em comum, é necessário que atividades humanas e modos de vida sejam valorados e posteriormente estimulados ou reprimidos, conforme os objetivos desejados. Supondo que não seja possível manter a ordem social apenas pelo uso da coerção, deve haver outros meios capazes de promover o engajamento dos indivíduos às atividades humanas positivamente valoradas e consideradas necessárias para a manutenção do modo de vida que se deseje. Para o objetivo da justificação, as sociedades engendram instituições, como a moral, a religião, a política, o direito, etc., que podem ser compreendidas como representações da realidade a que se agregam significados e valores, com o objetivo de orientar a conduta humana.

O sistema produtivo, em especial, também assume formas de organização que envolvem representações como o mercado de trabalho e a propriedade privada. Por meio dessas representações constitutivas do sistema produtivo, a maior parte dos indivíduos que não detém meios de produção aceita subordinar-se à orientação empresarial, alienando sua força de trabalho e o produto dela em troca de um salário que, salvo por injunções regulatórias estatais, deve ser definido pelo mecanismo do mercado. O produto do trabalho e os meios de produção (terra, matérias-primas 
e recursos tecnológicos) são concentrados sob a propriedade privada de uma minoria e estão sujeitos ao mesmo mecanismo da negociação mercantil.

Contudo, o modo como compreendemos o sistema produtivo é apenas o resultado da ação intelectual humana sobre a realidade com o objetivo de justificar um modo de organização da produção e distribuição da riqueza que, de outro modo, pareceria absurdo e injustificável. Para Polanyi (2000, p. 97), "a organização do trabalho é apenas um outro termo para as formas de vida do povo comum”.

A descrição do trabalho, da terra e do dinheiro como mercadorias é inteiramente fictícia. Não obstante, é com a ajuda dessa ficção que são organizados os mercados reais do trabalho, da terra e do dinheiro. Esses elementos são, na verdade, comprados e vendidos no mercado; sua oferta e procura são magnitudes reais, e quaisquer medidas ou políticas que possam inibir a formação de tais mercados poriam em risco, ipso facto, a autorregulação do sistema. A ficção da mercadoria, portanto, oferece um princípio de organização vital em relação à sociedade como um todo, afetando praticamente todas as suas instituições, nas formas mais variadas. Isto significa o princípio de acordo com o qual não se pode permitir qualquer entendimento ou comportamento que venha a impedir o funcionamento real do mecanismo de mercado nas linhas de ficção da mercadoria. Ora, em relação ao trabalho, à terra e ao dinheiro não se pode manter um tal postulado. Permitir que o mecanismo de mercado seja o único dirigente do destino dos seres humanos e do seu ambiente natural, e até mesmo o árbitro da quantidade e do uso do poder de compra, resultaria no desmoronamento da sociedade. Esta suposta mercadoria, a "força de trabalho", não pode ser impelida, usada indiscriminadamente, ou até mesmo não utilizada, sem afetar também o indivíduo humano que acontece de ser o portador dessa mercadoria peculiar. Ao dispor da força de trabalho de um homem, o sistema disporia também, incidentalmente, da entidade física, psicológica e moral do homem ligado a essa etiqueta. Despojados da cobertura protetora das instituições culturais, os seres humanos sucumbiriam sob os efeitos do abandono social; morreriam vítimas de um agudo transtorno social, através do vício, da perversão, do crime e da fome. A natureza seria reduzida a seus elementos mínimos, conspurcadas as paisagens e os arredores, poluídos os rios, a segurança militar ameaçada e destruído o poder de produzir alimentos e matériasprimas. Finalmente, a administração do poder de compra por parte do mercado liquidaria empresas periodicamente, pois as faltas e os excessos de dinheiro seriam tão desastrosos para os negócios como as enchentes e as secas nas sociedades primitivas. Os mercados de trabalho, terra e 
dinheiro são, sem dúvida, essenciais para uma economia de mercado. Entretanto, nenhuma sociedade suportaria os efeitos de um tal sistema de grosseiras ficções, mesmo por um período de tempo muito curto, a menos que a sua substância natural, assim como a organização de negócios, fosse protegida contra os assaltos desse moinho satânico (Polanyi, 2000, p. 94-95)

Representar a atividade humana como mercadoria, mensurável pelas grandezas de tempo e valor pecuniário, é o mesmo que submeter o próprio ser humano à lógica do mercado. A parcela dos agentes econômicos que têm o poder de determinar e gerir, sob a ficção da propriedade, os meios de produção, tem uma grande capacidade de influir na determinação, segundo seus interesses, dos preços das mercadorias que circulam no mercado: os produtos e serviços resultantes da atividade econômica e os salários pagos aos trabalhadores, que também assumirão o papel de consumidores. Deixar que o mecanismo do mercado regule a ação desses agentes econômicos independentes importa num elevado potencial de desequilíbrios que poderiam fazer ruir o sistema produtivo, em especial, pelo baixo poder de barganha e influência que os trabalhadores/consumidores, isoladamente, exercem sobre o sistema. É preciso a interferência de um agente externo que previna e evite esses desequilíbrios: o Estado.

Os sistemas públicos de seguridade social, que incluem a previdência social, talvez sejam o mais importante instrumento pelo qual a sociedade, por meio do Estado, interfere na economia para evitar que o mercado, pelo seu princípio de organização, a acumulação sob regime de concorrência, fomente a sua própria ruína. Por meio deles o Estado garante aos trabalhadores condições mínimas de segurança econômica para sua subsistência e reprodução, sem as quais dificilmente teriam o estímulo e as condições materiais para exercer o duplo papel que a economia de mercado lhes reserva: o de provedores de força de trabalho e o de consumidores dos bens e serviços produzidos.

\section{Trabalho Remunerado $X$ TrAbalho não REMUNERAdo}

"Ela não trabalha. É só dona de casa." Nessa sentença observa-se o uso do verbo trabalhar num sentido específico, incorporado ao emprego normal da palavra pelo senso comum. Ali não se quer dizer que a pessoa de quem se fala não exerça qualquer atividade laboral. Uma dona de casa realiza praticamente as mesmas atividades de uma empregada doméstica, a respeito de quem, contudo, não se costuma dizer: "Ela não trabalha. É apenas empregada doméstica."

A diferença fundamental que orienta o uso da língua em cada um desses casos está em que a atividade da dona de casa não é remunerada, enquanto a da empregada doméstica é. A atividade laboral da dona de casa está vinculada ao ambiente de privacidade familiar e é compreendida como uma obrigação natural, assumida tradicionalmente 
pelo seguimento feminino, de cuidado e assistência para com a família. Esse tipo de atividade não se insere na lógica do mercado: o cuidado da mãe com os filhos ou da esposa com o marido não é compreendido como algo substituível ou intercambiável por um bem equivalente. Essas relações familiares compreendem uma série de obrigações das quais não é moralmente aceitável desvincular-se completamente. Já a atividade da empregada doméstica, embora muito semelhante à da dona de casa, se insere na lógica do mercado. É compreendida como uma relação contratual, livremente assumida e facilmente rescindível. Admite-se que ela seja quantificada em termos de valor econômico equivalente, negociável e intercambiável no mercado.

O dinheiro é uma das abstrações que torna possível a existência de um mercado de trabalho. Somente após a conversão de diferentes tipos de atividades laborais avaliados qualitativamente de maneira diferente pela sociedade a um denominador comum pecuniário, é que se torna possível a comparação que viabiliza a negociação mercantil. O dinheiro expressa uma grandeza numérica que mede o valor qualitativo da atividade. Já o dimensionamento quantitativo da atividade laboral é comumente realizado pela medida do tempo de dedicação a ela. O tempo constitui a grandeza numérica que expressa o valor quantitativo do trabalho. Por meio da conjugação dessas duas grandezas é que o trabalho se torna um bem passível de submeter-se à lógica da negociação mercantil economicamente avaliável e intercambiável por outros bens. O tempo e o dinheiro são, contudo, meras abstrações. São agregados significativos atribuídos à atividade concreta do trabalho pela ação da mente humana.

A motivação importante para a atribuição desses agregados significativos abstratos ao trabalho concreto é o fato de que ele, como atividade humana situada no tempo, não pode ser estocado ou poupado. Somente a atribuição de valor pecuniário ao trabalho, e sua conversão em dinheiro, é capaz de gerar riqueza acumulável ou poupança. A análise dessas características é importante para a compreensão dos problemas que envolvem institutos como a previdência social, comumente compreendidos sob uma lógica de capitalização e de seguro. Tal concepção parte da ideia da formação, pelos trabalhadores, de uma espécie de poupança associada a um seguro individual para eventos imprevisíveis, por meio de contribuições em dinheiro ao longo de todo um período de vida laboral ativa. Tais institutos são compreendidos sob uma lógica contratual sinalagmática, pela qual às prestações dos trabalhadores devem corresponder, proporcionalmente, contraprestações do Estado. Os benefícios e prêmios futuramente auferidos nada mais seriam do que a contrapartida do esforço individual dos trabalhadores segurados sob a forma de contribuições feitas ao longo da vida laboral.

Se afastarmos essas abstrações jurídico-econômicas que envolvem a ideia de poupança e de seguro previdenciários associada aos sistemas de previdência social, percebemos que, concretamente, é o trabalho das gerações economicamente ativas em determinado período que provê os recursos necessários à manutenção e subsistência 
dos inativos daquela mesma época. O dinheiro que comporia a poupança previdenciária é apenas uma ficção que expressa a avaliação do trabalho realizado no passado, segundo valores de mercado fixados sob condições materiais de oferta e procura observados também no passado. É difícil garantir que o valor real dos benefícios previdenciários pagos numa determinada época aos aposentados, em termos de quantidade/qualidade de trabalho equivalente, correspondam ao que foi efetivamente "poupado" pelo trabalhador quando economicamente ativo.

Embora os sistemas jurídicos possam prever garantias de manutenção do valor nominal dos benefícios ou atualizações monetárias periódicas desses valores, são as condições futuras do mercado de trabalho e do mercado geral de bens e serviços, definidas por uma miríade de agentes econômicos independentes, que vão definir a quantidade/qualidade de trabalho equivalente que esses benefícios, expressos em valores monetários, poderão comprar. Apenas a intervenção de um agente regulador externo pode corrigir distorções que a ação livre do mercado poderia provocar na sustentabilidade do sistema previdenciário, impedindo a perda de valor de compra dos benefícios. Essa intervenção é prioritariamente orientada por motivações políticas, mas também por razões econômicas decorrentes do princípio da escassez. O valor real dos benefícios previdenciários pagos em determinada época dependerá da quantidade de trabalho extra a ser transformado em contribuições ao sistema previdenciário que o conjunto da sociedade, segundo uma avaliação política, concordar em prover, e, segundo uma avaliação econômica, tiver condições materiais de prover.

\section{TEMPO, DINHEIRO E PREVIDÊNCIA}

A concepção dos sistemas previdenciários como uma poupança formada ao longo dos anos de contribuição do trabalhador, que no futuro proverá os recursos necessários ao pagamento de benefícios e aposentadorias, é mais próxima da realidade dos sistemas privados de previdência. A suposta poupança previdenciária, contudo, não corresponde à realidade da maioria dos sistemas públicos de previdência, como o brasileiro. As contribuições pagas hoje são carreadas ao custeio dos atuais benefícios pagos pelo sistema em vez de serem guardadas para uso futuro. O tema recorrentemente debatido do "deficit da previdência" só faz sentido por meio de uma operação contábil que consiste em comparar o que sistema arrecada e o que ele provê em benefícios no presente. Não se coloca o problema em termos de sustentabilidade futura do sistema, senão no que concerne à avaliação perspectiva do crescimento do deficit pelo envelhecimento da população em comparação com os índices de crescimento da economia e da população como um todo.

No Brasil, o valor do deficit que se tem verificado há muitos anos é bastante discutido e questionado, em especial por serem contabilizados os gastos concernentes ao sistema de assistência social, que não se confunde com a previdência. Os recursos 
que faltam são custeados por outras fontes de arrecadação tributária. A concepção do sistema público de previdência brasileiro, inserido no contexto de um sistema mais amplo de seguridade social - que congrega subsistemas de saúde, previdência e assistência -, tal como previsto no texto constitucional, se afasta da lógica simplista de capitalização e de seguro individuais e consagra uma lógica de solidariedade social. Tal característica se mostra clara quando a constituição estabelece uma multiplicidade de fontes de custeio do sistema de seguridade social, que compete a toda a sociedade (art. 195), e quando define as ações concernentes ao sistema de seguridade social como de responsabilidade não só do Estado mas de toda a sociedade (art. 194). ${ }^{2}$

Com a emenda Constitucional n. 20/98 foram introduzidas algumas modificações no regime jurídico do sistema de previdência social brasileiro, que aparentemente impuseram contradições à lógica da sua concepção original, integrado ao sistema de seguridade social ${ }^{3}$ (art. 201). Contudo, deixando de lado o debate jurídico-político sobre o perfil da previdência social brasileira, cabe enfatizar que em sistemas públicos de previdência desse tipo não faz nenhum sentido o apelo à ideia de capitalização e de seguro individual (análoga ao modelo privado), senão como uma ficção para o efeito de uma justificação moral ou econômica do próprio sistema. A lógica dos sistemas públicos e privados de previdência está centrada não na ideia pura e simples de uma poupança de recursos financeiros. Para o mecanismo de funcionamento dos sistemas previdenciários, tão importante quanto à variável financeira, consistente no pagamento das contribuições, é a variável tempo, que consiste na fixação de períodos mínimos de contribuição e/ou idades mínimas para usufruto dos benefícios.

Nos sistemas públicos de previdência nos quais os aportes financeiros não são carreados para contas individuais dos respectivos contribuintes, o valor do tempo se mostra especialmente evidente. Não basta garantir dos contribuintes o aporte de um certo volume de recursos financeiros. Igualmente importante é garantir que cada um deles permaneça durante um considerável período de tempo economicamente ativo e produtivo, condição sem a qual não é possível auferir os benefícios do sistema.

No entanto, sabemos que tempo e dinheiro não passam de abstrações por meio das quais se torna possível a acumulação e a circulação do valor atribuído às atividades humanas reais que, consideradas em si mesmas, não se prestam à acumulação ou à circulação. O que os sistemas públicos de previdência pretendem com esse conjunto de requisitos (contribuições e prazos) é estimular as pessoas a empregarem seu tempo e vigor físico em uma atividade altamente valorizada: o trabalho remunerado. Isso tem um significado ético importante, a saber, que a sociedade apenas dará o suporte de compensação diferenciado da cobertura previdenciária, que não é acessível a todos, aos indivíduos que tenham dedicado boa parte de sua vida, em geral os anos de maior capacidade física e mental, às atividades produtivas suscetíveis de negociação mercantil. 
É sobre esse substrato real que a sociedade deposita o verdadeiro valor das riquezas que se expressam pela abstração do dinheiro, que só tem significado enquanto puder ser trocado por elas. Não fosse assim, bastaria que os indivíduos alcançassem um determinado nível de poupança, em dinheiro, para poder auferir dos benefícios dos sistemas públicos de previdência, que, entretanto, exigem a satisfação de requisitos associados à variável temporal: tempo de contribuição e idade mínima. Mas qual é a razão dessa valorização do tempo pelos sistemas previdenciários? O tempo nos remete à percepção de que a energia vital de que as pessoas se utilizam para desenvolver suas atividades é um recurso finito. Sabemos de antemão mais ou menos de quanto tempo podemos dispor durante um dia antes de precisar dormir e, embora não saibamos quantos dias teremos de vida, sabemos que com a velhice nosso vigor físico e disposição para o trabalho tendem progressivamente a diminuir até o seu esgotamento completo. Essa energia vital, seja ou não utilizada em determinado momento para a realização de atividades consideradas valiosas por nós ou pelos outros, também não pode ser acumulada, poupada ou transferida. ${ }^{4}$ Só faz sentido a acumulação de riqueza monetária na suposição de que, quando necessário, haverá oferta constante e segura de indivíduos dispostos, estimulados e capacitados, a empregar seu tempo e energia em atividades consideradas valiosas ou necessárias por aqueles que acumulam.

Parece pouco adequado o apelo a uma justificação moral dos sistemas públicos de previdência em sintonia com o contexto ético das sociedades capitalistas, que estimulam a conduta racionalmente orientada para objetivos individuais. Desse contexto ético se deduz a ideia de que cada um deve prover por seu próprio esforço os meios necessários à compensação da perda da capacidade de trabalho, na velhice. A análise dos sistemas previdenciários revela que sua justificação ética é mais consistente com a associação a um princípio de solidariedade social, traduzido pela ideia de um compromisso moral hipotético entre gerações: assim como a parcela da população economicamente ativa no presente concordou em empregar grande parte sua energia vital em atividades humanas (trabalho) necessárias a prover uma existência digna à sociedade como um todo, incluindo idosos e jovens, as próximas gerações têm a responsabilidade de assumir o mesmo encargo no futuro.

Em vez de interpretar as contribuições dos atuais trabalhadores como uma espécie de investimento, em vista de uma futura cobertura de segurança econômica na velhice ou em decorrência de eventos imprevisíveis, é também razoável, em termos éticos, compreendê-las como nada mais do que a retribuição ao investimento social, feito no passado pelos agora inativos, para prover à população ativa condições materiais (estímulo, capacitação, cuidados com saúde e assistência em geral) necessárias ao perfeito funcionamento do sistema produtivo, considerado a origem principal da riqueza social - o que demanda elevados investimentos de tempo, trabalho e dinheiro. 
O nível de qualidade de vida que as futuras gerações terão condições de prover à sociedade não depende exclusivamente de condicionantes a serem conhecidos no futuro. Depende também, com bastante intensidade, daquilo que fazemos hoje para prepará-las para assumir essa responsabilidade e dos encargos (endividamento, passivos ambiental e social, etc.) assumidos no presente, por toda a sociedade, a serem suportados no futuro. Se o que faz a riqueza de uma sociedade são as atividades humanas concretas que seus membros são capazes realizar e efetivamente realizam em certo momento histórico, na velhice, teremos uma sociedade tão mais rica quanto seja maior o investimento na capacitação e estimulação dos jovens de hoje para utilizar sua energia vital em atividades valiosas.

\section{5 ÊNFASE NO DINHEIRO X ÊNFASE NAS PESSOAS}

Essas reflexões nos encaminham para o reconhecimento da necessidade de uma reavaliação das atividades humanas em termos de seu valor e importância para as sociedades no presente e no futuro. No passado, esse questionamento foi respondido pelo filósofo Adam Smith no sentido de que "o trabalho é o fundo primitivo do qual qualquer nação obtém todas as necessidades e comodidades da vida que ela consome anualmente" (2009, p. 5). A valorização do trabalho, como origem da riqueza social, com o tempo, mais do que um conselho prático de ciência econômica, foi incorporado como um imperativo moral fundamental das sociedades capitalistas.

Na opinião de Reine Eisler (2008) é necessário um novo olhar sobre o que realmente importa para a geração e promoção de atividades humanas que agreguem valor ao modo de vida das sociedades. Em outros termos, é preciso rediscutir a origem da "verdadeira riqueza das nações". Para isso, deve-se considerar como parte integrante do sistema econômico setores até agora marginalizados, tidos por improdutivos, como a "economia familiar", a "economia comunitária não remunerada" (que engloba as ações sociais, de caridade e assistência, promovidas pela sociedade civil) e a "economia natural" (relativa ao cuidado com o meio-ambiente). A economia familiar, em especial, representaria nada menos que a base de sustentação de todo o sistema econômico:

Esse novo mapa econômico começa incluindo a família como o setor interno básico. Esse setor é a verdadeira essência da produtividade econômica, pois ele sustenta e torna possível a atividade econômica em todos os outros setores. O lar não é, como sugerem quase todos os textos de economia, apenas uma unidade de consumo. Ele é, e sempre foi, uma unidade de produção. O seu produto mais importante é, e sempre foi, o ser humano e este produto é de suma importância na economia pós-industrial na qual o "capital humano de alta qualidade" tornou-se um mantra comercial. 
Entretanto, nenhuma atenção é atribuída nas análises econômicas convencionais ao que é necessário para produzir esse capital humano de alta qualidade, a saber, atenção e assistência. (Eisler, 2008, p. 26)

Para Eisler existem enormes distorções no modo como são apurados os indicadores econômicos, como PIB e PNB, pelos quais é avaliada a riqueza de um país. Esses índices, em geral, não incluem as atividades de cuidado com as pessoas e com a natureza, pois as consideram como um passivo ou ônus social que reduz a eficiência do sistema econômico. Na verdade, deveriam considerá-las pelo que realmente representam: um investimento necessário e imprescindível para a manutenção da eficiência do sistema no presente e, principalmente, no futuro. Em contrapartida, avaliam positivamente, como geradoras de riqueza econômica, atividades que claramente representam um ônus social cuja eliminação, quando possível, seria altamente desejável. A autora menciona que, historicamente, no cálculo do PNB norte-americano foram contabilizadas positivamente despesas como: gastos bilionários necessários à limpeza do derramamento de óleo do petroleiro Exxon-Valdez em 1989; despesas com as campanhas militares no Iraque, incluindo despesas médicas com soldados mutilados e com funerais de militares mortos em combate, além das despesas para a reconstrução do país destruído pela guerra; lucros crescentes da "indústria penitenciária americana”, etc.

A "verdadeira riqueza de uma nação", defende Eisler, não reside em sua capacidade de gerar riqueza material, mas sim na "qualidade de seu capital humano e natural" (2008, p. 71). Não se nega a importância da economia de mercado, como a conhecemos hoje, para a manutenção do modo de vida que consideramos valioso. Contudo, especialmente na época em que vivemos, quando o conhecimento e o uso intensivo de tecnologia avançada ganharam importância fundamental para a produtividade, a eficiência e a competitividade das empresas, o investimento na formação de recursos humanos altamente qualificados é um pressuposto básico para o alcance desses objetivos estratégicos. O uso de máquinas sofisticadas e de outros recursos tecnológicos tem aumentado a eficiência das empresas em todos os setores da economia eliminando progressivamente uma enorme quantidade de ocupações, em especial na indústria e na agricultura, tradicionalmente ocupadas por empregados de baixa e média qualificação. O setor de serviços tem sido o caminho natural para a criação de novas ocupações em atividades para as quais se exigem aptidões que as máquinas e a tecnologia ainda não são capazes de substituir o homem, a saber, "criatividade, "flexibilidade e solidariedade".

O sistema econômico vigente, pela forma como atribui valor às atividades humanas, gera uma escassez artificial pela distribuição desproporcional e socialmente insensível da riqueza produzida. O uso intensivo de máquinas e de recursos tecnológicos produz uma abundante riqueza desigualmente apropriada por poucos, ao passo 
que crescentes parcelas da população seguem engajadas em atividades que, embora essenciais para toda a sociedade, não têm seu valor adequadamente reconhecido e recompensado. A introdução de tecnologias pós-industriais no sistema produtivo não precisa ser vista unicamente sob a óptica da problemática do desemprego, pela exclusão de uma massa de trabalhadores de baixa qualificação do mercado de trabalho. Se o que elas possibilitam é maior produtividade com menor esforço humano, deveriam ser recebidas como uma boa notícia. Na verdade, esse processo libera para o sistema econômico (entendido num sentido mais amplo) um excedente de "capital humano”, antes indisponível, que agora pode ser empregado em outras atividades. E há um enorme campo de necessidades sociais, em que as aptidões especificamente humanas não podem ser supridas por máquinas, para a aplicação desses recursos, a saber, em saúde, cuidados com os idosos e deficientes, educação - em especial a educação infantil, historicamente tratada com pouco profissionalismo -, etc.

Para Eisler, a revolução tecnológica pós-industrial abre oportunidade para uma "redefinição do que é trabalho produtivo de maneiras que utilizem as nossas aptidões humanas especiais". Para isso, é preciso "modificar as regras do jogo para que o trabalho essencial de cuidar de nós mesmos, dos nossos filhos e de uma população cada vez maior de idosos tenha um grande valor" (2008, p. 176). Não é possível deixar que o valor dessas atividades humanas de elevada importância social, indispensáveis para a manutenção e aperfeiçoamento do modo de vida que hoje consideramos valioso, seja arbitrado pelo mecanismo pretensamente imparcial do mercado, ao sabor do regime de oferta e procura. Continuar exigindo que pais e mães, para manter seu sustento, tenham que buscar o mercado de trabalho em condições cada vez mais precárias de empregabilidade, e sejam obrigados a não dar a atenção necessária à educação dos seus filhos - não somente a educação para o mercado de trabalho, que o Estado se adianta em suprir, mas especialmente a educação moral e emocional -, significa desperdiçar a possibilidade de um futuro mais próspero, humano e, certamente, economicamente mais rico.

\section{DEMOCRACIA E BALANÇO INTERGERACIONAL}

O enfrentamento de crises econômicas como as dos últimos anos, desde 2008, exige sacrifícios de governos e sociedades. O efeito imediato dessas crises, decorrente da progressiva perda de confiança do mercado na solvência das dívidas públicas que financiam as atividades estatais, é o aumento das taxas de juros na emissão de novos títulos para rolagem dessas dívidas. Cabe aqui destacar uma característica da denominada dívida pública que pode parecer um tanto curiosa. O Estado faz uso do endividamento público, por meio da emissão de títulos remunerados a taxas de juros variáveis, como um importante instrumento de regulação e de política macroeconômica, por meio do qual, dentre outros objetivos, interfere no volume de moeda em 
circulação, com impacto importante sobre a inflação e sobre as taxas de juros praticadas no mercado; em outras palavras, o Estado regula o poder de compra da moeda e o custo do crédito privado, condicionantes fundamentais para a atividade produtiva. O curioso no mecanismo de endividamento público (interno) é que o Estado se torna devedor de um bem que ele mesmo, e apenas ele, produz: a moeda.

Parece claro que o poder estatal de interferir na economia não corresponde a esse aparente e esdrúxulo monopólio que acabamos de retratar. É preciso fazer a ligação entre esses conceitos e institutos abstratos com elementos concretos da organização social do sistema produtivo. Modernamente, as taxas de juros das dívidas públicas têm funcionado como um importante indicador político nas democracias ocidentais. Nas palavras de Ferguson, (2007, p. 237-238), funcionam como uma "pesquisa de opinião diária":

... as flutuações dos de preço dos títulos públicos existentes - gerados pela política fiscal do passado - têm [...] influência importante na política fiscal presente e futura. Simplificando, se um governo quer tomar mais dinheiro emprestado emitindo mais títulos, a queda de preço dos títulos existentes é um grave desincentivo, pois implica forçosamente alta dos rendimentos de quaisquer novas emissões [...] A rigor, uma queda de preço dos títulos públicos pode ser interpretada como um "voto" de desconfiança do mercado na política fiscal, ou em qualquer política que o mercado interprete como aumentando a probabilidade calote, inflação ou depreciação. O preço e o rendimento dos títulos têm, pois, uma importância política que raramente é levada em conta pelos historiadores. É óbvio que resultam de uma infinidade de conjeturas dos investidores individuais e institucionais acerca da situação econômica como um todo. Mas, em certos sentidos, valem também como uma pesquisa de opinião diária, uma expressão de confiança no regime que está emitindo os títulos. Decerto, uma pesquisa de opinião baseada em uma amostragem pouquíssimo representativa segundo padrões democráticos (Ferguson, 2007, p. 237-238).

$\mathrm{Na}$ outra ponta, os governos são pressionados pelos eleitores. Mas o escrutínio de interesses políticos heterogêneos, e frequentemente contraditórios dos detentores do poder de voto, é complexo e tomado apenas pontualmente, de tempos em tempos, em eleições. À opinião pública cabe influenciar mais amiúde a representação política e oferecer resistência aos cortes de gastos sociais, inclusive nos benefícios previdenciários, demandados como solução para o reequilíbrio das finanças públicas.

Deixando de lado o mérito das demandas e o equilíbrio de forças entre os demandantes, frente à representação política democrática em determinado momento, qualquer que seja a tendência das políticas públicas adotadas - no sentido de afrouxar 
a política fiscal, tolerando o aumento da dívida pública, ou no sentido de uma política fiscal mais rígida, implicando o corte de gastos públicos -, uma parcela importante dentre os principais afetados por essas políticas não tem, nesse momento, qualquer influência sobre o processo decisório: os jovens (crianças e adolescentes) e os que ainda estão por nascer. É sobre eles que, no futuro, recairá a responsabilidade de, com seu trabalho, gerar a riqueza necessária para o pagamento dos encargos da dívida contraída hoje e para o pagamento de benefícios previdenciários e de outros tipos aos que hoje detêm o poder do voto.

A teoria econômica tem se preocupado em dar à análise das políticas públicas um conteúdo crítico em relação aos potenciais conflitos de interesses entre gerações presentes e futuras, por meio de conceitos como o de balanço intergeracional. 5 Para Ferguson, embora muitos países possam aparentemente ostentar relativo equilíbrio em sua política fiscal, quando analisada sob o ponto de vista do balanço intergeracional tal política pode mostrar-se nada menos que insustentável:

... um novo tipo de conflito distribucional vem substituindo o modelo tradicional baseado em classes, predominante no século XX. Em um certo sentido, o Estado previdenciário foi criado para pôr fim aos antigos conflitos entre rentistas, empresários e trabalhadores, e embora parte conseguiu isto. Mas o sucesso teve um preço - a criação de um sistema de benefícios universais que se tornou financeiramente insustentável. Com os balanços intergeracionais fora de prumo - como na maior parte da Europa, Japão e Estados Unidos -, é inevitável que substanciais cortes de despesas ou aumentos de impostos venham a ocorrer no futuro. Em um dos cenários, a próxima geração acabará por ser onerada com uma maior carga de impostos, arcando com as pensões e demais transferências que beneficiam a geração atual, inclusive os juros dos títulos (que constituem uma grande parcela das pensões privadas). Ou, então, acabará havendo redução nos benefícios para a terceira idade - por exemplo, mediante cortes nas pensões públicas, calote nos títulos do governo, ou uma forte e imprevista alta da inflação -, caso em que a conta é reapresentada à geração que contraiu as despesas anos antes Fergunson (2007, p. 255).

Em termos econômicos, não há nada que as gerações presentes possam fazer para escapar dessa dependência em relação às decisões políticas e econômicas das próximas gerações. O único modo de garantir que as futuras gerações não precisem cogitar da opção do calote aos compromissos assumidos hoje é cuidar para que tenhamos uma sociedade mais rica e próspera no futuro. Isso só parece possível por meio da decisão política de investir pesadamente no cuidado e na formação intelectual, emocional e moral das crianças. Para tanto, é necessário garantir aos seus pais ou responsáveis, no 
momento certo, tempo e um mínimo de segurança econômica. É preciso livrar as pessoas, pelo menos momentaneamente, da "armadilha do trabalho". Do ponto de vista moral, resta contar com o apelo ao argumento do compromisso ético entre gerações, se aos futuros adultos for possível reconhecer que boa parte dos recursos da dívida assumida no passado e que então lhes será apresentada foi empregada em seu benefício e em seu interesse.

\section{A armadilha do trabalho}

O modo de organização do sistema produtivo e do mercado de trabalho impõe a necessidade de relegar as atividades essenciais de cuidado e assistência a segundo plano. Os indivíduos desde muito cedo são confrontados com a necessidade de se engajar no sistema produtivo. O sistema educacional é voltado prioritariamente à produção de conhecimento útil à atividade econômica. A sociedade os pressiona para que assumam o quanto antes empregos dos quais possam auferir a renda necessária ao seu sustento e de seus dependentes. Desde que assumem a condição de provedores de meios de subsistência paras suas famílias, as pessoas se veem enredadas pela necessidade de manter uma fonte de renda estável durante um longo período de tempo e, quando possível, acumular uma poupança que lhes garanta alguma segurança econômica para eventos imprevistos.

Sob regimes políticos democráticos, é natural esperar que o Estado se encarregue das intervenções necessárias para que essas atividades humanas essenciais para a manutenção e sustentabilidade da sociedade alcancem um novo status e as pessoas por elas responsáveis sejam adequadamente recompensadas e reconhecidas. Para uma crítica da ação estatal nesse sentido, analisaremos alguns aspectos do sistema público de previdência brasileiro, tomado exemplificativamente. Esse sistema estimula uma corrida pelo atendimento das condições necessárias ao recebimento dos benefícios previdenciários o quanto antes pelo acúmulo de tempo de contribuição, para o que é necessário manter um emprego formal ou uma atividade que gere renda suficiente para contribuições como autônomo.

Para a aposentadoria por tempo de contribuição, por exemplo, são necessários 35 anos de contribuição para os homens e 30 anos para as mulheres. Supondo o início da vida laboral aos 23 anos (tempo razoavelmente suficiente para a conclusão do ensino médio e superior) é possível aos brasileiros e às brasileiras alcançarem condições de se aposentar, respectivamente, aos 58 e aos 53 anos de idade. No sistema de previdência dos servidores públicos, há a associação de idades mínimas (60 anos e 55 anos) a períodos de contribuição (35 anos e 30 anos) como requisitos para aposentadoria. Para as condições atuais e perspectivas futuras do mercado de trabalho, onde se observa uma tendência ao aumento de ocupações que exigem mais habilidades intelectuais do que vigor físico, pode-se considerar que pessoas nessa faixa etária (entre 53 e 60 
anos) estão ainda relativamente jovens para se aposentar, tendo condições ainda de permanecer por um bom tempo, pelo menos uns 10 ou 15 anos, em atividade.

Não se questiona, do ponto de vista ético, o fato de a sociedade conceder a possibilidade de se aposentar a pessoas que ainda tenham capacidade de trabalhar. Qualquer um que tenha trabalhado ininterruptamente por longos períodos, como 35 ou 30 anos, e contribuído adequadamente para o sistema previdenciário, há de ter direito a se aposentar e se dedicar a outras atividades, dessa vez livremente escolhidas e não sob a necessidade de manter uma renda para o sustento. O que parece ser um grave equívoco é que a sociedade permita a aposentadoria de pessoas relativamente jovens, liberando-as da necessidade do trabalho pela garantia de uma fonte de renda segura e permanente, ao mesmo tempo em que nega essa condição de poder dispor de tempo livre, com estabilidade e segurança, em outros períodos da sua vida nos quais teriam sido muito mais necessários.

\section{I A QUESTÃo DO GÊNERO}

Um bom exemplo da questão de gênero é a razão pela qual se justifica a concessão de aposentadoria às mulheres após um período de contribuição cinco anos menor que o dos homens. Concebe-se esse tratamento diferenciado como uma compensação pelas condições desfavoráveis e discriminatórias do mercado de trabalho para as mulheres, e pela necessidade que têm de conciliar uma dupla jornada como donas de casa e trabalhadoras assalariadas. Todavia, não há relação direta entre as condições do trabalho feminino e os requisitos mais favoráveis para aposentadoria: a concessão de aposentadoria em menor tempo não corrige ou atenua os problemas enfrentados pelas mulheres no mercado de trabalho. Para Mesquita e Balbinotto (2010): “O problema dessa justificação é que a aposentadoria por idade foi concebida como uma garantia contra a perda da capacidade de trabalho devido à idade e não deveria ser usada como um instrumento para corrigir discriminação baseada no gênero, real ou suposta". 6

A moderna filosofia moral e política ligada ao feminismo tem sido crítica dessas distorções, em especial, sobre o modo como as instituições sociais tentam promover a igualdade e combater a discriminação entre os sexos. Argumenta-se que, embora a maioria das sociedades contemporâneas tenha leis e institutos voltados à promoção da igualdade de gênero, essas garantias têm resultado prático limitado. Para a efetiva garantia de acesso igualitário entre os gêneros aos diversos espaços, atividades e posições sociais relevantes, inclusive o mercado de trabalho, ressalta a preocupação com a responsabilidade e o ônus do cuidado com os filhos em idade pré-escolar, função tradicionalmente desempenhada pela mulher. Essa atribuição importa num ônus social consideravelmente pesado, demandando dos indivíduos dela encarregados intensa dedicação ao longo de todo o dia, diuturnamente, por vários anos seguidos e, em geral, justamente no período em que estão na plenitude de sua capacidade laboral e 
no qual teriam maiores chances de sucesso na competição pelo mercado de trabalho e posições sociais de destaque. ${ }^{7}$

A mulher brasileira, ante a justa expectativa de maior liberdade e acesso aos diversos domínios da vida social, para além do ambiente doméstico, está sujeita a uma angustiante escolha - quando tenha acesso a meios contraceptivos - entre a carreira e a família. Uma intervenção estatal efetiva para enfrentar o tratamento discriminatório às mulheres seria a antecipação do tempo livre e da garantia de renda estável, dada como medida compensatória quando da aposentadoria, para gozo em períodos de suas vidas em que precisam conciliar o trabalho com a reprodução e o cuidado com a primeira infância dos filhos, ou para o enfrentamento de contingências, como a prestação de assistência por motivo de doença ou outro tipo de evento imprevisível - como dependência química ou delinquência que envolvam os filhos ou parentes próximos. Diante de tais eventos, que têm o potencial de gerar instabilidade e até mesmo desestruturar o equilíbrio e a subsistência familiar, é razoável supor que a maioria das mulheres, quando tenha essa opção, sacrificaria a carreira para dar o suporte de que a família necessita. No fim das contas, essas mulheres acabam tendo que se submeter à dependência econômica dos maridos, ou que se sujeitar a trabalhos mal remunerados ou, quando pouco, adiar suas expectativas de aposentadoria. Em qualquer desses casos, a situação das mulheres não parece melhor que a dos homens, seja na competição pelo mercado de trabalho, seja no que concerne às condições de aposentadoria em termos de tempo de espera e valor dos benefícios.

Sabe-se, contudo, que nem todas as mulheres enfrentam as mesmas dificuldades para acesso ao mercado de trabalho ou têm a mesma conduta quando se trata de optar entre dedicar seu tempo à família ou à carreira. Por outro lado, atividades tradicionalmente femininas têm sido assumidas cada vez mais por homens, sendo, ainda, comuns os casos de grupos familiares monoparentais ou sob a responsabilidade de casais homossexuais, nos quais, embora não haja a presença de mulheres, há potencialmente as mesmas dificuldades em conciliar a geração de renda no mercado de trabalho com o cuidado com a família. Além de ineficiente em relação aos seus propósitos, essa compensação pela redução do tempo de contribuição acaba se mostrando injusta, por ser orientada arbitrariamente pelo critério de gênero, sendo insensível a essas situações específicas que mereceriam, conforme o caso, inclusão ou exclusão do campo de incidência do tratamento diferenciado. Na pior das hipóteses, que lamentavelmente não é incomum, para os responsáveis pela subsistência de unidades familiares, homens ou mulheres, não está disponível a opção de prescindir de parte da renda familiar, ainda que momentaneamente, para o enfrentamento adequado de situações da vida que exigiriam maior dedicação de tempo e energia à família e afastamento da atividade laboral remunerada.

Independente do critério de gênero, é cada vez mais claro que as sociedades carecem que os indivíduos, no momento certo, dediquem seu tempo e sua energia vital às 
atividades do que poderíamos chamar de "economia familiar", atividades para as quais o Estado tem se mostrado incompetente e incapaz de substituir adequadamente as relações de solidariedade familiar. Sem isso, continuaremos assistindo ao aumento do número de jovens entregues ao vício das drogas e ao crescimento nos índices de criminalidade com elevados custos para a sociedade e para economia.

\subsection{TransformaÇões NO MERCADO DE TRABALHO}

Há ainda problemas na concepção do sistema público de previdência brasileiro, que parecem ser comuns a outros sistemas, para além de questões de gênero. É que o sistema permite a aposentadoria, em menos tempo e com valores mais elevados, para a parcela da população economicamente ativa que talvez seja a que menos necessite dessas "vantagens". Para que o trabalhador possa se aposentar o mais cedo possível é necessário que ele tenha condições de se manter ocupado, em um emprego formal, de modo estável, durante todo o tempo mínimo de contribuição exigido. Diante das condições atuais e tendências de estruturação do mercado de trabalho, tal feito tende a se tornar progressivamente mais difícil de realizar, passando a ser acessível apenas a uma parcela de trabalhadores de qualificação mais elevada e maiores condições de empregabilidade.

A introdução de novas tecnologias e processos no sistema produtivo tem sido responsável pela eliminação, em curto espaço de tempo, de diversas ocupações que faziam parte do cotidiano das empresas e que por vezes exigiam algum nível de qualificação. É difícil para as pessoas que passaram razoável tempo de suas vidas desenvolvendo habilidades necessárias ao exercício de atividades que deixaram de ser necessárias encontrar outras formas para manter uma fonte de renda e continuar vinculados aos sistemas previdenciários, pelo menos num curto espaço de tempo.

O mercado de trabalho registra uma profunda modificação do seu perfil organizacional, talvez sentida ainda com pouca intensidade no Brasil, mas já em larga expansão pelo mundo. As grandes empresas responsáveis pela produção do que se considera o grosso das riquezas nacionais e que, pelo seu porte, representam o alvo prioritário para a tributação estatal, têm adotado diversas estratégias para fugir da responsabilidade pelos encargos que a sociedade lhes impõe como contrapartida dos lucros obtidos pelo uso intensivo dos recursos humanos e naturais que a sociedade provê ou mantém.

Antes notabilizadas pelo seu gigantismo e por estruturas produtivas e burocráticas complexas, que procuravam ser autossuficientes em tudo o que é necessário aos seus objetivos empresariais, essas empresas têm procurado adotar estruturas organizacionais menos concentradoras e mais voltadas para a busca dos recursos necessários à sua atividade no mercado. Um conjunto de pequenos empreendimentos satélites passa a ser responsável, sob regime contratual de prestação de serviço, por uma série de pequenas parcelas daquilo que antes era executado pela própria empresa central, ora 
contratante. Essa última fica dispensada da necessidade de montar suas próprias estruturas, selecionar e treinar seus empregados e, em especial, arcar com os encargos sociais dessas atividades.

Dentre esses encargos, destaca-se o custo social de manter uma oferta perene de recursos humanos disponíveis e capacitados para a atividade laboral remunerada de que depende a economia empresarial, além dos custos de manutenção de condições de subsistência dessas pessoas após a perda de capacidade laboral, o que inclui saúde e previdência. Tais encargos não podem ser dissociados do valor de uso desse recurso social, a força de trabalho, em determinado momento e devem ser suportados por toda a sociedade, proporcionalmente, ao proveito que dele se aufere. Não se pode aceitar que a responsabilidade das empresas se encerre com o pagamento dos salários. ${ }^{8}$

Como resultado dessas estratégias empresariais, as atividades fiscais e arrecadatórias estatais tornam-se mais difíceis e dispendiosas ante a multiplicidade e menor porte das empresas submetidas ao seu poder de polícia: em relação ao cumprimento da legislação trabalhista e ao pagamento de impostos e contribuições destinadas ao custeio de prestações sociais. A organização sindical dos trabalhadores é dificultada, ante a sua dispersão em diversos núcleos e locais de trabalho, o que alivia a empresa de uma pressão potencialmente mais forte por aumento de salários.

As mudanças no mercado de trabalho atingem os trabalhadores de todos os níveis de qualificação. Se no passado o ideal de uma grande porção da população ativa de melhor qualificação era a conquista de um emprego em uma grande empresa, na qual fosse possível "fazer carreira" nos seus diversos setores e, com isso, poder contar com a relativa proteção e os benefícios que o seu gigantismo proporcionava, hoje, a ideia de "carreira" na iniciativa privada tende a ser um conceito cada vez mais inadequado para definir o relacionamento entre empresas e empregados. A acirrada concorrência de mercado exige dinamismo das empresas que, com frequência, necessitam mudar suas estratégias para obter sucesso. Manter pesadas estruturas produtivas e de pessoal adaptados a uma determinada estratégia empresarial não permite esse dinamismo. $\mathrm{O}$ custo de remodelar as estruturas produtivas e requalificar o pessoal é muito elevado. O ideal é que o relacionamento com os empregados se limite ao tempo necessário à realização de determinado objetivo empresarial, findo o qual deve findar também a relação de trabalho.

Essa relação não se dá mais em torno da ideia de "carreiras", mas da ideia de "projetos” (Boltanski et al., 2009, p. 117-129). Para se manter empregado não basta que o trabalhador procure uma qualificação específica - um diploma -, na expectativa de uma carreira que lhe garanta estabilidade e segurança, o que tende a ser cada vez mais raro. Ele precisa ser flexível, assim como as empresas têm de ser dinâmicas; precisa ter diversas qualificações que o habilitem a se engajar em diferentes projetos, conforme a necessidade do mercado. O que valoriza a qualidade do recurso humano deixa de ser a obtenção de títulos formais e passa a ser a sua empregabilidade. Apenas uma pequena 
parcela do universo dos trabalhadores tem condições de qualificação suficientes para se manter empregado permanentemente ante a dinâmica do mercado de trabalho. A maioria, devido à perda momentânea de condições de empregabilidade, terá que lidar com períodos variáveis de inatividade ou de engajamento em ocupações informais, até que adquira novas qualificações ou mudem as condições do mercado.

O que se observa é que as empresas transferiram um encargo que em grande medida tradicionalmente lhes cabia, o de qualificar e requalificar seus empregados, para os próprios trabalhadores e a sociedade. O sistema previdenciário, que deveria oferecer maior proteção aos que se mostram mais vulneráveis aos eventos da vida que retiram a capacidade de trabalho e de geração de renda, oferece condições mais favoráveis aos trabalhadores que menos precisam dessa proteção: os mais qualificados - condição que se deve a pesados investimentos custeados por toda a sociedade - que se podem se manter estavelmente empregados e, por isso, conseguem se aposentar mais cedo e com melhores benefícios.

$\mathrm{Na}$ prática, em especial no caso brasileiro, boa parte dos trabalhadores que conseguem se aposentar mais cedo acumula o recebimento do benefício previdenciário - que deveria suprir a perda de capacidade laboral -, com a renda de trabalho assalariado, mantendo-se no mercado de trabalho por muitos anos antes de efetivamente ingressar na inatividade.

\section{7·3 INICIATIVAS E ARgUMENTOS PRÁTICOS}

Sem a pretensão de prescrever soluções práticas capazes de resolver os problemas relacionados à configuração dos sistemas públicos de previdência, é possível em linhas gerais apontar argumentos e exemplos concretos que podem orientar uma reformulação desses sistemas em sintonia com sua importância para o equilíbrio e sustentabilidade da ordem social como um todo.

Os sistemas de previdência não podem ser interpretados como meros mecanismos de proteção dos indivíduos por ocasião da perda momentânea ou permanente da capacidade de trabalho, mas como parte de um conjunto mais amplo de garantias que agregam à ordem social o estímulo necessário para que os indivíduos continuem acreditando que vale a pena o engajamento no sistema de produção capitalista. Por essa razão, não faz sentido a segregação estrita dos sistemas públicos de previdência, no que concerne à avaliação dos custos e resultados, em relação aos sistemas de saúde e assistência. Mais adequado seria reforçar, a exemplo da redação original da Constituição brasileira de 1988, a ideia de um sistema integrado de seguridade social, congregando um conjunto de prestações em saúde, previdência e assistência, voltadas a um mesmo interesse público geral de dotar a sociedade como um todo dos meios necessários ao seu desenvolvimento e reprodução sustentáveis.

O sistema produtivo figura como o maior beneficiário desses mecanismos de proteção social em decorrência do uso intensivo que faz de recursos humanos gerados a 
custa de um elevado investimento social na formação intelectual, moral e emocional de indivíduos aptos ao ingresso no mercado de trabalho. É razoável que a contribuição para o custeio dessas prestações sociais, inclusive as de caráter previdenciário, seja proporcional ao proveito que delas se aufere. O pagamento de salários não compensa o investimento social prévio e os encargos posteriores (decorrentes do envelhecimento, de doenças ou de acidentes) necessários a que a força de trabalho esteja disponível em certo momento.

A sociedade necessita que os indivíduos em idade produtiva e reprodutiva tenham a garantia de uma renda estável que lhes assegure o afastamento da atividade laboral remunerada por períodos mais longos que os assegurados atualmente, para que possam se dedicar às diversas situações da vida que demandam maior dedicação à família. Em especial, destaca-se a conveniência de um afastamento mais prolongado para dedicação aos cuidados necessários com os filhos em idade pré-escolar, essencial para o pleno desenvolvimento intelectual e emocional da criança. ${ }^{9}$ Outra possibilidade seria a viabilização de afastamento remunerado que permitisse ao indivíduo buscar novas qualificações e, com isso, melhores condições de empregabilidade e de realização pessoal na atividade profissional escolhida. O usufruto de novas e mais prolongadas possibilidades de afastamento do trabalho, com garantia de renda, poderia ser compensada pelo equivalente aumento das idades mínimas para que os optantes alcançassem o direito aos benefícios voltados a suprir a perda da capacidade laboral.

Há um largo campo de atividades de interesse social, mas de pouco ou nenhum interesse na economia de mercado, que podem ser eficazmente incentivadas por semelhantes mecanismos de proteção social, para cujo acesso seja dispensado o prévio exercício de atividade laboral remunerada. Ainda no exemplo brasileiro, podemos citar programas de transferência de renda, como o "Bolsa Família", do governo federal, que oferece uma renda estável a famílias em situação de pobreza e de extrema pobreza, garantindo um mínimo de segurança alimentar e proteção a crianças que, sem esse auxílio, estariam expostas a grave situação de risco social; e o "Bolsa Floresta", do governo do estado do Amazonas, que, dentre outras iniciativas, provê um complemento de renda às famílias residentes em unidades de conservação ambiental, como suporte ao modo de vida e à economia de subsistência praticada nessas comunidades, promovendo a proteção do meio ambiente e o desenvolvimento sustentável.

A experiência brasileira mostra que, não havendo condições de conciliar adequadamente o trabalho remunerado com as necessidades vitais, por meio de mecanismos desse tipo, grande parte da população de baixa qualificação continuará “optando” pela informalidade laboral, contando com o denominado "benefício de prestação continuada”, de caráter assistencial, o qual, na prática, funciona como um sucedâneo de aposentadoria por idade, a partir dos 65 anos.

Ante a internacionalização do sistema produtivo, do mercado de trabalho e do mercado de consumo de bens e serviços, a eficácia de iniciativas desse tipo é fortemente 
dependente de que eventuais reformas sejam adotadas em nível global, sob pena de desequilíbrios que tornariam inviável sua implementação. Acreditamos seja esse o aspecto mais desafiador do problema a demandar um enorme esforço de entendimento político entre nações, aparentemente, ainda distante de ser concretizado.

\section{CONCLUSÃO}

A título de conclusão deste artigo apresentam-se os seguintes tópicos:

1. As crises financeiras internacionais têm trazido ao debate público a necessidade de maior intervenção do Estado na economia e a tensão entre o endividamento público dos países centrais do sistema capitalista internacional, e a demanda por prestações sociais nos campos da saúde, da previdência e da assistência. Destaca-se a recorrente demanda por reformas legais nos sistemas públicos de previdência, restringindo-se o acesso aos benefícios.

2. O trabalho representa um valor fundamental para a sociedade capitalista, que avalia e compara suas diversas modalidades por meio das grandezas tempo e dinheiro, possibilitando abstratamente a acumulação e circulação daquilo que, a rigor, não se prestaria a esse fim: a atividade humana concretamente situada no tempo. Essa atividade não pode ser tratada como mera mercadoria sujeita às leis do mercado. O pagamento de salários não exaure a responsabilidade social pela criação e manutenção de um contingente estável de pessoas capacitadas e estimuladas a dedicar seu tempo ao trabalho que gera a riqueza social. A força de trabalho não pode ser dissociada do substrato humano que a contém, com todas as suas necessidades e vicissitudes.

3. Os sistemas públicos de previdência podem ser compreendidos como uma ficção jurídico-econômica, por meio da qual as sociedades equacionam o problema inerente à condição humana de, no início e no fim de sua vida, ter limitada sua capacidade laboral, sendo necessário tornar perene a garantia de segurança econômica ao longo de sua existência. Esses sistemas, embora sejam comumente interpretados segundo um modelo contratual, sob uma lógica de capitalização ou de seguro (os benefícios devem ser estritamente proporcionais às contribuições dos beneficiários), quando afastadas as abstrações jurídico-econômicas neles envolvidas, podem ser melhor compreendidos sob a lógica de um compromisso de solidariedade social entre gerações: o compromisso de que a parcela da população que a cada momento encontrar-se na plenitude de sua capacidade laboral deve prover as atividades humanas necessárias ao sustento de toda a sociedade. 
4. Os sistemas públicos de previdência funcionam como instrumento de intervenção Estatal na economia para evitar que o mercado, pelo seu modo de organização, exaura a capacidade da sociedade de prover os recursos humanos necessários à atividade produtiva. Por meio deles o Estado dá aos trabalhadores condições mínimas de segurança econômica, garantindo sua subsistência e reprodução. Sem essas condições mínimas, os indivíduos dificilmente teriam o estímulo e as condições materiais necessários para exercer o duplo papel que a economia de mercado contemporânea espera deles: o de fornecedores de força de trabalho e o de consumidores dos bens e serviços produzidos.

5. A valorização das atividades relacionadas à economia de mercado e a desvalorização de outras atividades humanas que, embora não remuneradas, são essenciais para a manutenção do modo de vida que conhecemos, como o cuidado e a assistência, assumidos tradicionalmente como obrigações de solidariedade familiar, têm forçado a busca por posições no mercado de trabalho em prejuízo dessas outras atividades. Em contrapartida, o Estado é chamado a substituir a família por meio de prestações a cargo de sistemas de seguridade social, havendo intensa contestação quanto à sustentabilidade financeira desses sistemas, em longo prazo, ante o crescimento das demandas sociais.

6. Sendo o cuidado e a assistência essenciais para a manutenção da vida humana em sociedade, a simples restrição das prestações estatais, ante a pressão pelo controle do endividamento público, não parece ser uma alternativa. Sugere-se uma revalorização dessas atividades humanas não remuneradas e o oferecimento de condições materiais para que os indivíduos possam, eles mesmos, prover o cuidado e a assistência de que suas famílias e pessoas próximas necessitem, especialmente pela garantia, no momento certo, de tempo (afastamento do trabalho remunerado) e estabilidade econômica. Os sistemas públicos de previdência podem funcionar como instrumento para esses fins. 


\section{NOTAS}

1 Para uma análise crítica aprofundada sobre a lógica organizacional do sistema capitalista, v. Wallerstein, 2001, p. 13-40 e Boltanski et al., 2009, p. 31-60.

2 "Ao associar as ações de previdência, assistência e saúde num corpo integrado e ao se estruturar com base no princípio da universalidade da cobertura e atendimento, o sistema de proteção social definido na Constituição Federal prevê garantias contra contingências sociais que ameacem a sobrevivência do indivíduo. Nesse sentido, tal concepção de proteção vai além da concessão de benefício em caso de perda de capacidade de trabalho, que é o comumente associado a estruturas previdenciárias em termos estritos. Essa concepção se afasta da ideia da previdência como 'seguro', em que a pessoa tem um contrato e direitos individuais e, quando ocorre o evento previsto, recebe algum benefício de acordo com o que contribuiu. Na Seguridade prevalecem o contrato social e os direitos sociais, em que a necessidade do cidadão prepondera sobre suas eventuais contribuições para o sistema. [...] Esse sistema - no qual os benefícios da previdência, assistência e saúde são direitos garantidos pela cidadania, de acordo com a Constituição Federal brasileira - não poderia ter sustentação apenas nas contribuições incidentes sobre as folhas de salários e sobre os rendimentos dos trabalhadores. [...] Como visto, a Constituição Federal, no art. 194, explicita - como um dos princípios estruturantes do sistema - a diversidade de fontes de financiamento e, no art. 195, indica essas fontes, não as vinculando a cada um dos três eixos de políticas - saúde, assistência e previdência -, que, ao contrário, constituem um sistema integrado de proteção social. [...] A diversificação das fontes de financiamento também tornou o sistema menos refém do ciclo econômico. Ou seja, um sistema de proteção social financiado exclusivamente por contribuições de trabalhadores e empresas sobre folha sofreria duplamente em períodos de recessão econômica, com suas receitas se contraindo e suas despesas aumentando. Com base mais ampla de financiamento, a Seguridade Social brasileira apresenta menor vulnerabilidade frente às oscilações da economia. Além disso, a incidência de contribuições sobre lucro e faturamento possibilita melhor distribuição do peso de sustentação do sistema, impedindo que os setores intensivos em trabalho sejam sobrecarregados" (Dieese, 2007).

3 "Entre outras medidas, a Emenda Constitucional n. 20 introduziu o princípio do "equilíbrio financeiro e atuarial” na organização da previdência pública. [...] A imposição rígida de critérios de equilíbrio financeiro e atuarial limita o objetivo redistributivo da Seguridade Social e pode vir a colocar em risco alguns tipos de aposentadorias, em especial aquelas cujos valores de benefício não guardam relação direta com contribuições acumuladas. A lógica de equilíbrio financeiro e atuarial é muito mais adequada ao conceito de 'seguro' previdenciário como direito individual e, portanto, em última instância, está em contradição com a concepção dos benefícios da Seguridade como direitos de cidadania” (Dieese, 2007).

4 Para uma análise filosófica profunda e elegante sobre o tema "tempo" e sua relação com a economia e a vida das pessoas em geral, ver Giannetti, 2005, p. 193-209.

5 "Balanço intergeracional é simplesmente o valor líquido de todos os impostos pagos ao longo de uma vida inteira - ou, mais precisamente, a diferença entre todos os impostos que os cidadãos nascidos em um ano qualquer irão pagar futuramente, ao longo da vida inteira, em se mantendo a política vigente, e todas as transferências por ele recebidas. Comparando-se o balanço intergeracional dos recém-nascidos de hoje com o balanço de recém-nascidos no futuro, efetuadas as devidas correções de crescimento demográfico e econômico, obtém-se, pois, uma medida precisa do equilíbrio ou desequilíbrio intergeracional. Se os balanços intergeracionais das gerações futuras são mais elevados que o balanço dos recém-nascidos de hoje, isto significa que a política de hoje apresenta um desequilíbrio intergeracional e, portanto, é insustentável" (Ferguson, 2007, p. 250)

6 "The problem with this reasoning is that old-age retirement was conceived as an insurance against the loss of capacity for work due to old age, and should not be used as an instrument to correct gender-based discrimination, real or supposed."

7 "Considere o fato de que a maioria dos trabalhos "exigem que a pessoa, neutra quanto ao gênero, que esteja qualificada para eles seja alguém que não é guardião primário de uma criança em idade pré-escolar” (Mackinnon, 1987, p. 37). Dado que ainda se espera que as mulheres tomem conta dos filhos em nossa sociedade, os homens tenderão a se sair melhor do que as mulheres ao competir por tais trabalhos. Isso não acontece porque haja discriminação contra as mulheres candidatas. Os empregadores podem não dar atenção ao gênero dos candidatos ou podem, na verdade, desejar contratar mais mulheres. O problema é que muitas mulheres 
carecem de qualificação relevante para o trabalho - isto é, serem livres de responsabilidades pelo cuidado dos filhos. Há neutralidade quanto ao gênero no fato de que os empregadores não atentam para o gênero dos candidatos, mas não há igualdade sexual, pois o trabalho foi definido com o pressuposto de que seria preenchido por homens que tivessem mulheres em casa, cuidando dos filhos. [...] Essa incompatibilidade que os homens originaram entre a criação dos filhos e o trabalho remunerado tem resultados profundamente desiguais para as mulheres. O resultado é não apenas que as posições mais valorizadas da sociedade são ocupadas por homens, enquanto as mulheres encontram-se desproporcionalmente concentradas no trabalho de meio período e com salário mais baixo, mas também que muitas mulheres tornam-se economicamente dependentes dos homens.” (Kymlicka, 2006, p. 308-309)

8 O trabalho, como se sabe, é uma ficção jurídica quando considerado como mercadoria destacável daquele que o produz (Polanyi, 1983; Supiot, 1997). O "recurso humano" não pode ser consumido como os outros, pois supõe um custo de manutenção e reprodução que deveria ser indissociável de seu custo de utilização. Aquele que compra um tomate paga, em princípio, seu custo de fabricação desde a geração da semente, passando pela terra, pela fertilização e pelos cuidados que lhe foram dispensados. Ele não se limita a alugar o tomate pelo tempo que ele demora para passar do prato ao estômago. No entanto, é diante de uma situação desse tipo que nos vemos com frequência cada vez maior no que se refere ao trabalho, pois estão sendo cada vez mais separados dos salários pagos os custos incorridos antes do emprego (escola, formação, sustento durante períodos de inatividade e folgas), ou depois dele (reconstituição das forças, desgaste e envelhecimento), sem contar que o efeito da intensificação sobre a saúde física e mental não é positivo. Essa situação é mais problemática porque a "produção" do "recurso humano" é demorada, tal como ocorre com certas árvores que são plantadas muito tempo antes da colheita; os efeitos da situação atual, portanto, se farão sentir ao longo de várias décadas. Os custos de manutenção e reprodução do trabalho foram assim em grande parte transferidos para os indivíduos e para os dispositivos públicos, reforçando nos primeiros as desigualdades associadas aos rendimentos - visto que os mais pobres não podem se manter e se reproduzir sem ajuda -, e acentuando no segundo a crise do Estado-providência, obrigado a impor novas contribuições, o que possibilita às empresas eximir-se cada vez mais de suas responsabilidades, num círculo vicioso de que os fenômenos socioeconômicos oferecem numerosos exemplos" (Boltanski et al., 2009, p. 279-280).

9 Sobre o tema, incluindo o relato de políticas públicas concretas no sentido descrito no texto, conferir Teixeira, 2010.

\section{REFERÊNCIAS BIBLIOGRÁFICAS}

BOLTANSKI, L.; CHIAPELLO, È. O novo espírito do capitalismo. São Paulo: Martins Fontes, 2009. DIEESE. Nota Técnica: Previdência social brasileira: concepção constitucional e tentativas de desconstrução. n. 51, set. 2007.

EISLER, R. A verdadeira riqueza das nações. São Paulo: Cultrix, 2008.

FERGUSON, N. A lógica do dinheiro: riqueza e poder no mundo moderno 1700-2000. Rio de Janeiro:

Record, 2007.

GIANNETTI, E. O valor do amanhã. São Paulo: Companhia das Letras, 2005.

KYMLICKA, W. Filosofia política contemporânea. São Paulo: Martins Fontes, 2006.

MESQUITA, R.; BALBINOTTO NETO, G. Regulatory Shortcomings of Brazilian Social Security. Economic Analysis of Law Review, América do Norte, v. 1, n. 1, 2010. Disponível em: <http://portalrevistas.ucb.br/ index.php/EALR/article/view/1468/1120>. Acesso em: 6 abr. 2011.

POLANYI, K. A grande transformação. 2. ed. Rio de Janeiro: Elsevier, 2000.

SMITH, A. An inquiry into the nature and causes of the wealth of the nations. Digireads.com, 2009.

Disponível em: <http://books.google.com.br/books?id=rBiqT86BGQEC\&lpg=PA1\&dq=

adam $\% 20$ smith $\% 20$ wealth $\% 20 \mathrm{of} \% 20$ nations\&hl=pt-br\&pg $=\mathrm{PA} 3 \# \mathrm{v}=$ onepage\& $\mathrm{q} \& \mathrm{f}=\mathrm{false}>$. Acesso em:

7 abr. 2011.

TEIXEIRA, D. V. Desigualdade de gênero: sobre garantias e responsabilidades sociais de homens e mulheres. Revista Direito GV, São Paulo, v. 6, n. 1, 2010. Disponível em: 


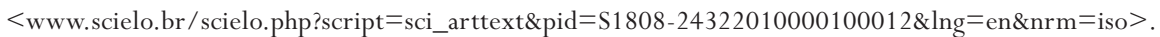
Acesso em: 17 nov. 2011.

WALLERSTEIN, I. Capitalismo histórico e civilização capitalista. Rio de Janeiro: Contraponto, 2001.

\section{Daniel Viana Teixeira}

Av. Santos Dumont, n. $1890-4^{\circ}$ andar Aldeota - 60150-160 Fortaleza - CE - Brasil daniel.teixeiralaagu.gov.br
Mestre em Direito Constitucional da Universidade DE FORTALEZA (UNIFOR) Procurador Federal da Advocacia-Geral da União 
